\title{
GROWTH PERFORMANCE OF THE GIANT FRESHWATER PRAWN, Macrobrachium rosenbergii JUVENILE FED ON A BASAL DIET CONTAINING DIFFERENT ZINC CONCENTRATIONS
}

\author{
D.M.S.D. EL-Saidy ${ }^{1}$ and Madlin M. Habashy ${ }^{2}$ \\ 1- Department of Poultry Production, Faculty of Agriculture, University of Minufiya, Shebin El- \\ Kom, Egypt., P.O.Box 32516. E.mail: devabelsaidy@yahoo.com, 2- National Institute of \\ Oceanography and Fisheries, Fish Research Station, El-Qanater El-Khayria, Egypt
}

\section{SUMMARY}

The main objectives of this study were to evaluate the effects of zinc on growth performance, survival, feed utilization and body composition of the giant freshwater prawn, Macrobrachium rosenbergii juvenile. Eight diets were formulated with 0 (control), 10, 30, 50, 70, 90, 110 and $130 \mathrm{mg}$ $\mathrm{Zn} \mathrm{kg}^{-1}$ of diet as Zinc sulphate $\left(\mathrm{ZnSo}_{4} .7 \mathrm{H}_{2} \mathrm{O}\right)$. Fish meal, soybean meal, bread flour and wheat meddling were used as an ingredient of the basal diet which contained $36.7 \%$ crude protein and used as control diet without zinc supplementation. Twenty post-larvae of Macrobrachium rosenbergii of mean length of $1.45 \pm 0.01 \mathrm{~cm}$ and weight of $0.022 \pm 0.001 \mathrm{~g}$ were stocked in each aquarium, set in triplicate groups. The experiment continued for 12 weeks.

The results revealed that, the best growth performance and survival rate were obtained with groups of prawn fed diet supplemented with $70 \mathrm{mg} \mathrm{Zn} \mathrm{kg}{ }^{-1}$ diet. Best feed conversion ratio (FCR), feed efficiency ratio (FER), protein efficiency ratio (PER) and feed intake were obtained with diet supplemented with $70 \mathrm{mg} \mathrm{Zn} \mathrm{kg} \mathrm{kg}^{-1}$ and $90 \mathrm{mg} \mathrm{Zn} \mathrm{kg}^{-1}$ of diet as compared to 0 control, 10, 30, 50,110,

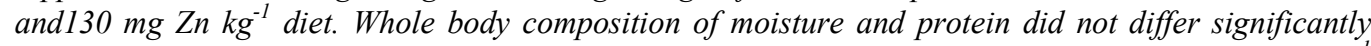
among treatments. The highest lipid content was obtained with the groups of prawn fed $30 \mathrm{mg} \mathrm{Zn} \mathrm{\textrm {kg } ^ { - 1 }}$ diet compared with the others. Whole body ash increased significantly with the increasing of zinc level.

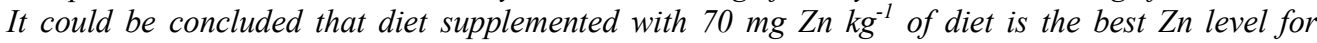
feeding of the giant freshwater prawn, Macrobrachium rosenbergii under the experimental condition.

Keywords: Growth, survival, feed utilization, body composition, zinc levels, Macrobrachium rosenbergii

\section{INTRODUCTION}

Historically, freshwater prawns of the genus Macrobrachium have been esteemed as food in many parts of the world. Of this group, the giant prawn of the Indo-Pacific, $M$. rosenbergii, has become so popular and has received a great deal of attention as a preferred crustacean. It grows fastest among all freshwater prawn (Mukhopadhyay et al., 2003). Like most animals, crustaceans require small amounts of minerals, to support a number of key metabolic processes (DeSilva and Anderson, 1995). Minerals act as biocatalysts for enzymes, hormones, and proteins or form components for hard-tissues matrices (exoskeleton), soft-tissues, and as cofactors or activators of enzymes. Minerals are also involved in maintenance of osmoregulation, $\mathrm{pH}$ balance and membrane potential (Davis and Lawrence, 1997).

Complete dietary mineral requirement for $M$. rosenbergii is not yet elucidated and knowledge of qualitative and quantitative requirements is scantly (Kanazawa et al., 1984). Some authors suggested that prawn may obtain minerals from ambient water, however, the importance of dietary minerals has been supported by the demonstrated ability of prawn to absorb inorganic minerals from diets and levels of some minerals such as calcium and magnesium in the carapace peaked at intermolt and declined during pre-molt of prawn. The minerals content in the carapace can be affected by the levels of minerals in the diet (Mukhopadhyay et al., 2003).

Trace elements are not only the basic units of the skeletal structures of animals but also important co-factors for enzymes and other biological chemicals involved in life processes. The importance of zinc as a diet component has gained considerable attention in the past few years. Zinc has an important role in numerous biological processes in avian, mammalian and aquatic species. For instance, zinc is an essential component of many enzymes (Vallee and Auld, 1990), and it has both structural and catalytic functions system and is a component of a large number of metallo enzymes. Furthermore, dietary zinc is required for normal immune response and an adequate dietary $\mathrm{Zn}$ concentration for nonspecific immune responses in Penaeus monodon is about $35-48 \mathrm{mg} \mathrm{Zn/kg} \mathrm{diet} \mathrm{(Shiau}$ 
and Jiang, 2006). It is an essential element required for normal growth and is indispensable in the diet (Yamaguchi, 1998). Rath and Dube (1994) stated that zinc has a significant role on growth promotion and survivability of the freshwater prawn. However, studies regarding nutritional requirement of zinc are confined to rainbow trout (Ogino and Yang 1978 and Kenox et al., 1984) and Nile tilapia (Magouz, 2002).

In the present study an attempt has been made to study the effect of the trace element zinc in promoting growth, survival, feed utilization and body composition of $M$. rosenbergii larvae.

\section{MATERIALS AND METHODS}

\section{Diet preparation:}

Experimental practical basal diet formulation and proximate analysis is tabulated in Table (1) to be adequate for $M$. rosenbergii (36.7\% crude protein). The basal diet was divided to eight portions and Zinc sulphate $\left(\mathrm{ZnSo}_{4} \cdot 7 \mathrm{H}_{2} \mathrm{O}\right)$ was added to the diets at levels of 0 (control) , 10, 30, 50, 70, 90, 110, $130 \mathrm{mg} \mathrm{Zn} \mathrm{Kg}{ }^{-1}$ diet. Zinc sulphate was dissolved in $400 \mathrm{ml}$ distilled water and subsequently was well mixed with the dry components, until stiff dough resulted. This was then passed through a mincer with die and the resulting "Spaghetti-like" strings were dried using an electrical fan at $22{ }^{\circ} \mathrm{C}$. After drying, the diets were broken up and sieved into convenient pellet sizes and stored at $20^{\circ} \mathrm{C}$.

\section{Experimental system and animals:}

The feeding trial was conducted in 24 glass aquaria each containing 80-liter of dechlorinated tap water. About one third of water volume in each aquarium was daily replaced by aerated fresh water after cleaning and removing the accumulated excreta. All aquaria were supplied with compressed air for oxygen requirements. A photoperiod of 12-h light, 12-h dark (08.00 to $20.00 \mathrm{~h}$ ) was used. Fluorescent ceiling lights supplied the illumination.

Water temperature and dissolved oxygen were measured every other day using a YSI Model 58 oxygen meter. Total ammonia and nitrite were measured twice weekly using a DREL, 2000 spectrophotometer. Total alkalinity and chloride were monitored twice weekly using the titration method; $\mathrm{pH}$ was monitored twice weekly using an electronic $\mathrm{pH}$ meter ( $\mathrm{pH}$ pen; Fisher Scientific, Cincinnati, $\mathrm{OH})$. During the 12-weeks feeding trial, the water-quality parameters averaged ( $\pm \mathrm{SD})$ : water temperature, $26.8 \pm 0.9{ }^{\circ} \mathrm{C}$ : dissolved oxygen, $5.6 \pm 0.7 \mathrm{mg} \mathrm{l}^{-1}$ : total ammonia, $0.19 \pm$ $0.12 \mathrm{mg} \mathrm{l}^{-1}$ : nitrite, $0.07 \pm 0.03 \mathrm{mg} \mathrm{l}^{-1}$ : total alkalinity, $178 \pm 42 \mathrm{mg} \mathrm{l}^{-1}$ : chlorides, $570 \pm$ $152 \mathrm{mg} \mathrm{l}^{-1}: \mathrm{pH}, 8.4 \pm 0.3$.

A set of 480 juvenile $M$. rosenbergii average initial length of $1.45 \pm 0.01 \mathrm{~cm}$ and weight of $0.022 \pm 0.001 \mathrm{~g}$ were collected from the stock at Fish Research Laboratory in Shebin El-Kom, Faculty of Agriculture, Minufiya University and were used for the feeding trial. Twenty juvenile were randomly stocked into each aquarium with triplicate per treatment. After stocking, to minimize stress of handling, 10 prawns from each aquarium were measured and weighed every two weeks and at the end of the feeding trial. All prawns were fed at $5 \%$ of the total body weight daily. Prawns were fed twice a day (0800 and 1600 h) six days per week for 12 weeks.

Growth performance and feed conversion were measured in terms of final individual weight $(\mathrm{g})$, survival rate $(\%)$, specific growth rate $\left(\mathrm{SGR}, \% \mathrm{day}^{-1}\right)$, feed conversion ratio (FCR), protein efficiency ratio (PER), and feed intake ( $\%$ body weight). Growth response parameters were calculated as follows: SGR $\left(\%\right.$ day $\left.^{-1}\right)=\left(\left\{\right.\right.$ In $W_{t}-$ In $\left.\left.W_{i}\right\} / T\right) \times 100$, where $\mathrm{W}_{\mathrm{t}}$ is the weight at time $\mathrm{t}, \mathrm{W}_{\mathrm{i}}$ is the weight at time 0 , and $\mathrm{T}$ is the rearing period in days: $\mathrm{FCR}=$ total dry feed fed $(\mathrm{g}) /$ total wet weight gain $(\mathrm{g})$ : PER = wet weight gain $(\mathrm{g}) /$ amount of protein fed $(\mathrm{g})$ : Feed intake $=$ total dry feed fed $\left(\mathrm{g}\right.$ fish $\left.{ }^{-1}\right)$ (Richardson et al., 1985).

\section{Chemical analysis:}

At the end of the experiment a random sample of five individual prawns were collected from each aquaria. They were pooled, ground, stored in polyethylene bags and freeze for subsequent body crude protein, lipid, moisture and ash contents determined according to AOAC (1995).

The $\mathrm{Zn}$ concentrations of the eight diets and prawn carcasses were also analyzed according to AOAC (1995). Proximate composition of test diets and prawn carcasses were determined in triplicate according to the following procedures: Moisture after drying at $105^{\circ} \mathrm{C}$ for 24 h., Protein $(\mathrm{N} \times 6.25)$ by Kjeldahl method after acid digestion, ash by incineration at $550{ }^{\circ} \mathrm{C}$ for $16 \mathrm{~h}$. Crude lipid was determined by the ether-extraction method using a Soxtec System HT (Soxtec System HT6, Tecator, Sweden). Metabolizable energy (ME) was estimated from the diet ingredient according to NRC (1993).

\section{Statistical analysis:}

Data were analyzed using the SAS ANOVA procedure (1988). Duncan's multiple range test (Duncan, 1955) was used to compare differences among treatments. Treatment effects were considered significant at $\mathrm{P} \leq 0.05$. 
All percentage and ratio were transformed to arc sin values prior to analysis (Zar, 1984).

\section{RESULTS}

During the 12 weeks exposure period of $M$. rosenbergii larvae to different dietary zinc levels, the highest significant $(\mathrm{P}<0.01)$ final length $(4.45 \mathrm{~cm})$, weight $(0.616 \mathrm{~g})$ and condition factor $(K)(0.90)$ were found for prawn fed 70 $\mathrm{mg} \mathrm{Zn} \mathrm{kg}{ }^{-1}$ diet, followed by those fed on 90 mg Zn kg ${ }^{-1}$ diet. While the lowest values for length and weight were recorded for prawn fed on $130 \mathrm{mg} \mathrm{Zn} \mathrm{kg}{ }^{-1}$ diet, being $2.85 \mathrm{~cm}$ for length and $0.166 \mathrm{~g}$ for weight (Table 2 and Figures 1 and 2).

The results indicated that the highest gain in length, weight and specific growth rate was recorded for prawn larvae fed on $70 \mathrm{mg} \mathrm{Zn} \mathrm{kg}^{-}$ ${ }^{1}$ diet. The lowest value was listed for those fed on diet containing $130 \mathrm{mg} \mathrm{Zn} \mathrm{kg}{ }^{-1}$ diet (Table $3)$. The maximum significant $(\mathrm{P} \leq 0.01)$ survival rate $(77.5 \%)$ was achieved by prawn larvae fed on $70 \mathrm{mg} \mathrm{Zn} \mathrm{kg}{ }^{-1}$ diet followed by those fed on $90 \mathrm{mg} \mathrm{Zn} \mathrm{kg}{ }^{-1}$ diet. However, the lowest value of survival $(17.5 \%)$ was obtained with prawn fed on the highest dietary zinc level $130 \mathrm{mg} \mathrm{Zn}$ $\mathrm{kg}^{-1}$ diet (Table 3).

The results revealed the highest values $(\mathrm{P} \leq 0.01)$ of feed intake, feed efficiency ratio (FER) and protein utilization measured as protein efficiency ratio (PER) were recorded for prawn fed on diet supplemented with 70 and $90 \mathrm{mg} \mathrm{Zn} \mathrm{kg}{ }^{-1}$ diet. However, the best values of feed conversion ratio (FCR) were recorded for groups of prawn fed the same two diets (Table 4).

It is obvious from the data that there were no significant differences for both of protein and moisture contents. While, lipid showed a slightly differences the highest significant value $(14.9 \%)$ for larvae fed on diet supplemented with $30 \mathrm{mg} \mathrm{Zn} \mathrm{kg}{ }^{-1}$ diet. For ash content it was found that as zinc level increase ash increase so, the highest significant $(\mathrm{P}<0.01)$ values were observed for those fed on diets containing 110 and $130 \mathrm{mg} \mathrm{Zn} \mathrm{kg}{ }^{-1}$ diet (Table 5).

\section{DISCUSSION}

It has been known that zinc is essential to life as an integral part of more than 200 enzymes isolated from different species (Vallee, 1988). Meanwhile, critical functions of zinc in DNA metabolism have been confirmed and numerous findings have greatly amplified the general significance of zinc in cell biology (Hao and Maret, 2006). It is generally considered that a dietary source of some minerals for growth is necessary because of the repeated losses of certain minerals during molting (Niu et al., 2008). The essentiality of dietary zinc for normal growth of $M$. rosenbergii larvae was clearly demonstrated in the present study. It was found that weight and length gain were recorded for prawn larvae fed on diet supplemented with 70 $\mathrm{mg} \mathrm{Zn} \mathrm{kg}{ }^{-1}$ diet. Specific growth rate (SGR \% day $^{-1}$ ), best FCR, feed intake, FER, PER and survival rate \% were also for larvae fed on the same diet followed by those fed on $90 \mathrm{mg} \mathrm{Zn}$ $\mathrm{kg}^{-1}$ diet. Zinc supplemented diet on the other hand, resulted in an improvement and enhancing growth performance and feed utilization of prawn larvae. There was a linear increase of these parameters with increasing levels of zinc supplementation to the diet up to optimum level $70 \mathrm{mg} \mathrm{Zn} \mathrm{kg}^{-1}$ diet. A further increase in zinc supplementation does not improve growth performance or feed utilization of the prawn. These results are in confirm with that obtained by Shiau and Jiang (2006) who stated that weight gain was reduced for the shrimp (Penaeus monodon) fed the unsupplemented basal diet and increased with increase in dietary $\mathrm{Zn}$ up to the requirement level. In this respect, Rath and Dube (1994) recorded that deletion of Zinc from the diet of $M$. rosenbergii stunted the growth and led to poor FCR, SGR and survival rate in comparison to the other diets supplemented with zinc. Zinc accumulation in the body tissue differs with concentration of zinc supplemented in diet. For other trace elements such as iron, El- Serafy et al. (2007) suggested that final body weight, SGR and best FCR were the highest in fish (Oreochromis niloticus) fed on the diet supplemented with $1200 \mathrm{mg} \mathrm{Fe} \mathrm{kg}^{-1}$ diet. On the contrary, low concentration of dietary cadmium caused a decrease in food utilization and reduced growth of tilapia (Oreochromis urolepis). Cadmium in the diet probably inhibits intestinal absorption and transport of food and essential minerals thought the gut wall (Pratap, 1999).

In contrast, the study with Litopenaeus vannamei showed that weight gain of the shrimp did not respond to the dietary $\mathrm{Zn}$ supplementation (Davis and Lawrence, 1993). On the other hand, $\mathrm{Wu}$ and Chen (2005) demonstrated that significant growth retardation was observed in shrimp exposed to $0.6 \mathrm{mg} \mathrm{Zn} 1^{-1}$, the average body weight and length of shrimp exposed to 0.2 and $0.6 \mathrm{mg} \mathrm{Zn}$ $1^{-1}$ were generally lower than those of control group, which might be related to the decrease in their food consumption rates as well as changes in nutritional conditions. Moza et al. (1995) recorded that gold fish, Cararssius auratus fed cadmium food have retained the feed in the gut for a longer duration than the controls and a decrease in feed intake and protein digestibility has been reported in gold 
fish exposed to water-borne cadmium. A similar decrease in the absorption and feeding was observed in catfish reared in ambient mercury (Sivakami et al., 1995). In this respect, Farmer et al. (1979) found a reduced feeed intake have been reported in Atlantic salmon exposed to zinc.

For other fishes, it has observed that dietary zinc affects not only appetite, growth and mortality, but also the level of zinc, iron and copper in the tissue of rainbow trout (Satoh et $a l ., 1983)$. Deficiency of zinc is found to cause poor growth performance, high mortality, erosion of fins and skin, dwarfism and cataract in rainbow trout (Wekell et al., 1983) and in Nile tilapia (Magouz, 2002). However, Ketola (1979) demonstrated that zinc availability in white fish meal is insufficient for good fish performance to protect rainbow trout from cataract formation, and an external $\mathrm{Zn}$ source was essential to eliminate the pathologies.

Diet is considered the major source of zinc for prawn larvae, and the increase of FBW and SGR are associated with increasing levels of zinc in the diet up to optimum level after which they were reduced. These results are in harmony with the findings of Davis and Lawrence (1993), Rath and Dube (1994) and Shiau and Jiang (2006) who demonstrated that zinc may have positive effect on metabolism, growth and food consumption of organisms. Gomez et al. (1999) recorded that zinc can influence bone mineralization either directly, as divalent action acting on nucleation and mineral accumulation, or indirectly, as a cofactor of enzymes or other metalloenzymes involved in the processes. The reported study here in showed that the highest gain in both length and weight of prawn was observed for prawn larvae fed on $70 \mathrm{mg} \mathrm{Zn} \mathrm{kg}{ }^{-1}$ diet followed by those fed on $90 \mathrm{mg} \mathrm{Zn} \mathrm{kg}{ }^{-1}$ diet. Hence, lower and excess zinc supplementation gives lower results.

The lowest values of survival rate were recorded for larvae fed on diets having excess element (110 and $130 \mathrm{mg} \mathrm{Zn} \mathrm{kg}^{-1}$ diet), indicates that excess of element in the diet increases mortality rate and this results in accordance with that obtained by Rath and Dube (1994) who observed that the best survival rate was for prawn fed on diet supplemented with $90 \mathrm{mg} \mathrm{Zn} \mathrm{kg} \mathrm{kg}^{-1}$ diet. Element increase in diet decreased the survival rate.

Study on the effect of cadmium and zinc on the growth, food consumption of white shrimp, Litopenaeus vannamei revealed that $\mathrm{Zn}$ showed milder effects on growth of shrimp compared to $\mathrm{Cd}$ and body weight and length of shrimp exposed to $0.6 \mathrm{mg} \mathrm{Zn} / 1$ and $0.2 \mathrm{mg} \mathrm{Zn/1}$ were generally lower than those of control group (free from $\mathrm{Zn}$ ). Scope for growth is a measure of the energy budget that is the difference between the energy absorbed from food intake and energy metabolized, and gives an indication of the metabolic condition of an organism (Rinderhagen et al., 2000). Moore and Farrar (1996) reported that growth rates significantly decreased with reduced food rations in the amphipod Hyalella azteca. It is reasonable that growth retardation may result from a decrease in feed intake.

The proximate composition of the final prawn carcass showed no significant differences in both of moisture and protein contents between different dietary treatments. Ash content increased significantly $(\mathrm{P}<0.01)$ with increasing zinc level in the diet. The highest values were recorded for prawn fed on 110 and $130 \mathrm{mg} \mathrm{Zn} \mathrm{kg}^{-1}$ diet. Slightly lipid content differences between treatments were observed the highest value was found for prawn fed on $30 \mathrm{mg} \mathrm{Zn} \mathrm{kg}{ }^{-1}$ diet. These results are in agreement with that obtained by Cheng et al. (2005) who reported that there were no significant differences in crude protein, lipid and moisture of abdomen muscle of shrimp, Litopenaeus vannamei fed different levels of dietary magnesium, while ash content increase with increasing magnesium supplementation in the diet.

\section{CONCLUSION}

The best growth performance, feed intake, FCR, FER, PER and survival were obtained for prawn larvae fed on diet supplemented with $70 \mathrm{mg} \mathrm{Zn} \mathrm{kg}{ }^{-1}$ diet in comparison with the control group and the other dietary treatments. Whole body composition of moisture and protein did not differ significantly among treatments. The highest lipid content was observed for those fed on $30 \mathrm{mg} \mathrm{Zn} \mathrm{kg}{ }^{-1}$ diet. While, whole body ash content increased significantly with increasing zinc level in the diet. Diet supplemented with $70 \mathrm{mg} \mathrm{Zn} \mathrm{kg}^{-1}$ diet is the best for feeding of $M$. rosenbergii larvae compared with other diets under the experimental conditions.

\section{ACKNOWLEDGMENT}

The financial support provided by the Minufiya University College of Agriculture, Shebin El-Kom, Egypt, for our Fish Research Laboratory is greatly acknowledged

\section{REFERENCES}

Association of Official Analytical Chemists (AOAC), 1995. Official Methods of Analysis of Official Analytical Chemists International, $16^{\text {th }}$ ed. Association of Analytical Chemists, Arlington, VA. 
Cheng, K.M., C.Q. Hu, Y.N. Liu, S.X. Zheng and J.Q. Qi, 2005. Dietary magnesium requirement and physiological responses of marine shrimp Litopenaeus vannamei reared in low salinity water. Aquaculture Nutrition; 11: 185-393.

Davis D.A. and A.I. Lawrence, 1993. Evaluation of the dietary zinc requirement of Penaeus vannamei and effects of phytic acid on zinc and phosphorus bioavailability. Journal of The World Aquaculture Society; 24: 40-47.

Davis, D.A. and A.I. Lawrence, 1997. Minerals in crustaceans nutrition (D, Abramo L.R.,Conklin, D.E. and Akiyama D.M., eds). The Aquaculture World Society. Baton Rouge. Pp 150-163.

DeSilva S.S. and T.A. Anderson, 1995. Fish Nutrition in Aquaculture. Aquaculture series 1. Chapman \& Hall, London. P139.

Duncan D.B., 1955. Multiple range and multiple F tests: biometrics 11, 1-42.

El-Serafy S.S., El-Ezabi M.M., Shehata T.M. and N. Esmael, 2007. Dietary iron requirement of the Nile tilapia, Oreochromis niloticus (L.) fingerlings in intensive fish culture. Egyptian Journal of Aquatic Biology and Fisheries; 11: 165184.

Farmer G.J., Ashfied D. and H.S Samant., 1979. Effects of zinc on juvenile Atlantic salmon Salmo salar. Acute toxicity and food intake, growth and bioaccumulation. Environmental Pollution; 19: 103-117.

Gomez S., Rizzo R., Pozzi-Mucelli M., Bonucci E. and F. Vittur, 1999. Zinc mapping in bone tissue by histochemistry and synchrotron radiation-induced $\mathrm{X}$ ray emission: correlation with the distribution of alkaline phosphatase. Booe ;25: 33-38.

Hao Q. and W. Maret, 2006. Imbalance between pro-oxidant and pro-antioxidant functions of zinc in disease. Journal Alzheimer's Disease; 8: 161-170.

Kanazawa A., Teshima S. and M. Sasaki, 1984. requirements of the juvenile prawn for calcium, phosphorus, magnesium, potassium, copper, manganese and iron. Mem. Fac. Fish. Kagoshima Univ.;33:6371.

Kenox D., Cowey C.B. and J.W. Adron, 1984. Effects of dietary zinc intake upon copper metabolism in rainbow trout (Salmo gairderi). Aquaculture; 40: 199-207.

Ketola H.G., 1979. Influence of dietary zinc on cataract in rainbow trout (Salmo gairdneri). Journal Nutrition ;109: 965-969.

Magouz F.I., 2002. Effect of different zinc and protein levels on growth performance and feed efficiency of Nile tilapia. In the proceedings of The $2^{\text {nd }}$ Scientific Conference on Food borne Contamination and Egyptians Health, 23-24 April, 2002 El-Mansoura, Egypt, 313-328.

Moore D.W. and J.D. Farrar, 1996. Effect of growth on reproduction in the freshwater amphipod, Hyalella azteca (Sauaaure). Hydrobiologia; 188/189: 517-523.

Moza U., Silva S.S. and B.M. Mitchell, 1995. Effect of sublethal concentrations of cadmium on food intake, growth and digestibility in gold fish Carassius auratus. Journal Environmental Biology; 16: 253264.

Mukhopadhyay P.K., Rangacharyulu P.V., Mitra G. and B.B. Jana, 2003. Applied nutrition in freshwater Prawn, Macrobrachium rosenbergii, culture. Journal Applied Aquaculture ;13: 317 -340.

National Research Council (NRC), 1993. Nutrient requirements of warm water fishes and shellfishes, 114pp National Academy Press, Washington, DC, USA.

Niu J., Liu Y.J., Tian L.X., Mai K.S., Yang H.J., Ye C.X. and W. Gao, 2008. Effect of dietary phosphorus source and varying levels of supplemental phosphorus on survival growth and body composition of post larval shrimp (Litopenaeus vannamei). Aquaculture Nutrition; 14: 472- 479.

Ogino C. and G. Yang, 1978. Requirement of rainbow trout for dietary zinc. Bull. Jpn. Soc. Sci. Fish. ;44: 1015-1018.

Pratap H.B.,1999. Effects of dietary cadmium on growth and food conversion in the freshwater cichlid Oreochromis urolepis. Journal Aquaculture in The Tropics; 14: 85-91.

Rath G.S. and K. Dube, 1994. Role of zinc in promoting growth and survival of $M$. rosenbergii. Journal Aquaculture in The Tropics; 9: $209-222$.

Richardson N. I., Higgs D. A., Beames R. M. and J.R. MC Bride, 1985. Influence of dietary calcium, phosphorus, Zinc and sodium phytate levels on cataract incidence, growth and histopathology in juvenile Chinook salmon, Oncorhynchus tshayvytscha. Journal of Nutrition; 115: 553-567.

Rinderhagen M., Ritterhoff J. and G.P. Zauke, 2000. Biomonitoring of polluted water reviews on actual topics: crustaceans as bioindicators. In Gerhardt A. (Ed) Environmental Research Forum, Vol 9. Transtecxh Publications- Scitech Publications, Phoenix, AZ, USA, P161194.

Satoh S., Yamamoto H., Takeuchi T. and T. Watanabe, 1983. Effects on growth and mineral composition of crap of deletion of trace elements or magnesium from fish meal diet. Bull. Jpn. Soc. Sci. Fish.; 49: 431-435. 
Shiau S.Y. and L.C. Jiang, 2006. Dietary zinc requirements of grass shrimp, Penaeus monodon, and effects on immune responses. Aquaculture; 254: 476-482.

Sivakami R., Premkishore G. and M.R. Chandran, 1995. Sublethal effects of mercury on feeding energetic and body composition of the freshwater catfish Mystus vittatus (Bloch). Journal Aquaculture in The Tropics ;10:109-118.

Statistical Analysis System (SAS), 1988. SAS/STAT user's guide release 6.03 edition. SAS Institute Inc. Cary, North Carolina, USA.

Vallee B.L., 1988. Zinc: biochemistry, physiology, toxicology and clinical pathology. BioFactors 1, 31-36.

Vallee B.L. and D.S. Auld, 1990. The metallobiochemistry of zinc enzymes, in:
MEISTER, A. (Ed) Advances in Enzymology, pp. 283-429 (New York, John Wiley).

Wekell J.C., Shearer K.D. and C.R. Houle, 1983. High zinc supplementation of rainbow trout diets. The Progressive FishCulturist; 45: 144-147.

Wu J.P. and H.C Chen., 2005. Effects of cadmium and zinc on the growth, food consumption and nutritional conditions of the white shrimp, Litopenaeus vannamei (Boone). Bull. Environ. Cotam. Toxicol.; 74: 234-241.

Yamaguchi M., 1998. Role of zinc in bone formation and bone resorption. J. Trace Elem. Exp. Med.; 11: 119-135.

Zar J. H., 1984. Bio-statistical Analysis, 2nd edition. Prentice-Hall International, Inc. Englewood Cliffs, New Jersey, USA.

Table 1. Composition and proximate analysis of the practical basal diet used.

\begin{tabular}{|c|c|c|c|c|c|c|}
\hline \multicolumn{5}{|l|}{ Ingredients } & \multicolumn{2}{|l|}{$\%$} \\
\hline \multicolumn{5}{|c|}{ Fish meal (60\% CP) } & \multicolumn{2}{|l|}{40} \\
\hline \multicolumn{5}{|c|}{ Soybean meal (44\% CP) } & \multicolumn{2}{|l|}{20} \\
\hline \multicolumn{5}{|l|}{ Bread flour } & \multicolumn{2}{|l|}{20} \\
\hline \multicolumn{4}{|c|}{ Wheat meddling } & \multirow{2}{*}{\multicolumn{3}{|c|}{$\begin{array}{l}10 \\
2.5\end{array}$}} \\
\hline \multicolumn{4}{|l|}{ Soybean oil } & & & \\
\hline \multicolumn{4}{|l|}{ Fish oil } & \multicolumn{3}{|c|}{2.5} \\
\hline \multicolumn{4}{|l|}{ Vit-mixture $^{1}$} & \multicolumn{3}{|c|}{2.0} \\
\hline \multicolumn{4}{|c|}{ Min-mixture $^{2}$} & \multicolumn{3}{|c|}{1.0} \\
\hline \multicolumn{4}{|c|}{ Ca-sulphate } & \multicolumn{3}{|c|}{2.0} \\
\hline \multicolumn{4}{|l|}{ Total } & \multicolumn{3}{|c|}{100} \\
\hline \multicolumn{7}{|c|}{ Proximate composition $(\%)$} \\
\hline \multicolumn{4}{|c|}{ Moisture } & \multicolumn{3}{|c|}{5.3} \\
\hline \multicolumn{4}{|c|}{ Crude protein } & \multicolumn{3}{|c|}{36.7} \\
\hline \multicolumn{4}{|l|}{ Crude Lipid } & \multicolumn{3}{|c|}{11.9} \\
\hline \multicolumn{4}{|l|}{ Crude ash } & \multicolumn{3}{|c|}{13.6} \\
\hline Crude fiber & & & & & 4.10 & \\
\hline Nitrogen fr & extract (NFE) & & & & 28.4 & \\
\hline Met. Energy & kcal kg ${ }^{-1}$ diet $)^{3}$ & & & & 3675 & \\
\hline $\begin{array}{l}{ }^{1} \text { Vitamin mi } \\
0.833 \text {; nicoti } \\
\text { tocopherol } \\
2 \text { monophosp } \\
{ }^{2} \mathrm{Mineral} \mathrm{mix} \mathrm{H}_{2} \mathrm{O}, 165 ; \mathrm{K} \\
\mathrm{MnSO}_{4} \cdot \mathrm{H}_{2} \mathrm{O} \text {, }\end{array}$ & $\begin{array}{l}\mathrm{re}\left(\mathrm{mg} \mathrm{g}^{-1}\right): \text { par } \\
\text { acid o.2667; th } \\
\text { tate, } 10 ; \text { cyano } \\
\text { e } \mathrm{Mg}, 1.4815 ; \mathrm{c} \\
\text { e zinc free }(\mathrm{mg} \\
1,139.53 ; \mathrm{KI}, 0 \\
07 ; \mathrm{CoCl}_{2} .6 \mathrm{H}_{2} \mathrm{C}\end{array}$ & $\begin{array}{l}\text {-aminobenzoic } \\
\text { amine-hydroch } \\
\text { obalamine, } 0.0 \\
\text { colinechloride } 2 \\
\left.\mathrm{~g}^{-1}\right) \mathrm{NaH}_{2} \mathrm{PO}_{4} \text {, } \\
\text { 23; } \mathrm{MgSO}_{4} 7 \mathrm{H}_{2} \\
\text { 1.4. }\end{array}$ & $\begin{array}{l}\text { id,10; inosit } \\
\text { ide, 0.5185; } \\
\text { 4; cholecalc } \\
6296 \text {; d-biot } \\
\text { 5; Ca }\left(\mathrm{H}_{2} \mathrm{PO}\right. \\
100 ; \mathrm{FeC}_{6} \mathrm{H}\end{array}$ & $\begin{array}{l}\text { 100; pyridoxir } \\
\text { inol acetate, } 0.6 \\
\text { erol, } 0.0037 ; \\
0.0889 ; \text { calcium } \\
\mathrm{H}_{2} \mathrm{O}, 265 ; \mathrm{Ca} \\
\mathrm{nH}_{2} \mathrm{O}, 10 ; \mathrm{CuC}\end{array}$ & $\begin{array}{l}\text { e-hydrochloride, } \\
44 \text {; menadione, } \\
\text { olicacid } 0.077 \\
\text { pantothenate, } 5 \text {. } \\
\mathrm{O}_{3}, 105 ; \mathrm{Ca}(\mathrm{CH} \\
2 \mathrm{H}_{2} \mathrm{O}, 0.15 ; \mathrm{Al}\end{array}$ & $\begin{array}{l}\text { 1.5; riboflavin } \\
\text { 1.4815; Alpha- } \\
\text { L-ascorbyle- } \\
481 \text {. } \\
\text { CHOHCOO) } \\
l_{3} .6 \mathrm{H}_{2} \mathrm{O}, 0.24\end{array}$ \\
\hline $\begin{array}{l}\text { Table } 2 . \text { At } \\
\text { larvae fed }\end{array}$ & $\begin{array}{l}\text { age }(X \pm S E) \\
h \text { practical } b\end{array}$ & $\begin{array}{l}\text { ength weight } \\
\text { sal diet with }\end{array}$ & $\begin{array}{l}\text { d conditiol } \\
\text { led level o }\end{array}$ & $\begin{array}{l}\text { actor of } M a \\
\text { inc }(n=3)\end{array}$ & achium & bergii post- \\
\hline $\begin{array}{c}\text { Zinc conc. } \\
\left(\mathrm{mg} \mathrm{kg}^{-1}\right. \\
\text { diet })\end{array}$ & $\begin{array}{c}\text { Initial } \\
\text { Length }(\mathrm{cm})\end{array}$ & $\begin{array}{c}\text { Initial } \\
\text { Weight (g) }\end{array}$ & $\begin{array}{l}\text { Condition } \\
\text { Factor }(\mathrm{K})\end{array}$ & $\begin{array}{c}\text { Final } \\
\text { Length }(\mathrm{cm})\end{array}$ & $\begin{array}{c}\text { Final } \\
\text { Weight }(g)\end{array}$ & $\begin{array}{l}\text { Condition } \\
\text { Factor }(\mathrm{K})\end{array}$ \\
\hline Control & $1.45 \pm 0.01$ & $0.022 \pm 0.001$ & $0.72 \pm 0.01$ & $2.82 \pm 0.02^{\mathrm{fg}}$ & $0.201 \pm 0.01^{\mathrm{ef}}$ & $0.70 \pm 0.01^{\mathrm{cd}}$ \\
\hline 10 & $1.45 \pm 0.01$ & $0.022 \pm 0.001$ & $0.72 \pm 0.01$ & $3.14 \pm 0.01^{\mathrm{e}}$ & $0.235 \pm 0.01^{\mathrm{e}}$ & $0.76 \pm 0.01^{\mathrm{bc}}$ \\
\hline 30 & $1.45 \pm 0.01$ & $0.022 \pm 0.001$ & $0.72 \pm 0.01$ & $3.71 \pm 0.02^{\mathrm{d}}$ & $0.306 \pm 0.01^{\mathrm{d}}$ & $0.60 \pm 0.00^{\mathrm{e}}$ \\
\hline 50 & $1.45 \pm 0.01$ & $0.022 \pm 0.001$ & $0.72 \pm 0.01$ & $3.88 \pm 0.03^{\mathrm{c}}$ & $0.365 \pm 0.02^{\mathrm{c}}$ & $0.63 \pm 0.03^{\mathrm{de}}$ \\
\hline 70 & $1.45 \pm 0.01$ & $0.022 \pm 0.001$ & $0.72 \pm 0.01$ & $4.45 \pm 0.06^{\mathrm{a}}$ & $0.616 \pm 0.01^{\mathrm{a}}$ & $0.90 \pm 0.04^{\mathrm{a}}$ \\
\hline 90 & $1.45 \pm 0.01$ & $0.022 \pm 0.001$ & $0.72 \pm 0.01$ & $4.19 \pm 0.02^{\mathrm{b}}$ & $0.500 \pm 0.02^{\mathrm{b}}$ & $0.69 \pm 0.02^{\mathrm{cd}}$ \\
\hline 110 & $1.45 \pm 0.01$ & $0.022 \pm 0.001$ & $0.72 \pm 0.01$ & $2.96 \pm 0.06^{\mathrm{f}}$ & $0.207 \pm 0.01^{\mathrm{e}}$ & $0.80 \pm 0.01^{\mathrm{b}}$ \\
\hline 130 & $1.45 \pm 0.01$ & $0.022 \pm 0.001$ & $0.72 \pm 0.01$ & $2.85 \pm 0.05^{\mathrm{g}}$ & $0.166 \pm 0.01^{\mathrm{f}}$ & $0.72 \pm 0.05^{b}$ \\
\hline
\end{tabular}

Means in the same column bearing different superscript letters differ significantly at $\mathrm{P} \leq 0.01$ 
Table 3. Average $(X \pm S E)$ gain in length, average gain in weight, specific growth rate and survival rate (\%) of Macrobrachium rosenbergii post-larvae fed with practical basal diet with graded level of zinc $(n=3)$

\begin{tabular}{ccccccc}
\hline $\begin{array}{c}\text { Zinc conc. } \\
\left(\mathrm{mg} \mathrm{kg}^{-1}\right. \\
\text { diet })\end{array}$ & $\begin{array}{c}\text { Average } \\
\text { gain in } \\
\text { length }(\mathrm{cm})\end{array}$ & $\begin{array}{c}\text { Average } \\
\text { gain in } \\
\text { weight }(\mathrm{g})\end{array}$ & $\begin{array}{c}\text { Average } \\
\text { gain in } \\
\text { length }(\%)\end{array}$ & $\begin{array}{c}\text { Average gain } \\
\text { in weight } \\
(\%)\end{array}$ & $\begin{array}{c}\text { Specific } \\
\text { growth rate } \\
\left(\% \text { day }^{-1}\right)\end{array}$ & $\begin{array}{c}\text { Average } \\
\text { survival rate } \\
(\%)\end{array}$ \\
\hline control & $1.37 \pm 0.02^{\mathrm{g}}$ & $0.175 \pm 0.01^{\mathrm{ef}}$ & $94.1 \pm 1.04^{\mathrm{g}}$ & $811.4 \pm 25.0^{\mathrm{ef}}$ & $3.1 \pm 0.04^{\mathrm{f}}$ & $70.0 \pm 5.0^{\mathrm{ab}}$ \\
10 & $1.69 \pm 0.01^{\mathrm{e}}$ & $0.215 \pm 0.01^{\mathrm{e}}$ & $116.2 \pm 0.35^{\mathrm{e}}$ & $966.0 \pm 20.5^{\mathrm{e}}$ & $3.3 \pm 0.03^{\mathrm{e}}$ & $57.5 \pm 7.5^{\mathrm{ab}}$ \\
30 & $2.26 \pm 0.02^{\mathrm{d}}$ & $0.285 \pm 0.01^{\mathrm{d}}$ & $155.9 \pm 1.38^{\mathrm{d}}$ & $1290.9 \pm 31.8^{\mathrm{d}}$ & $3.7 \pm 0.04^{\mathrm{d}}$ & $55.0 \pm 5.0^{\mathrm{b}}$ \\
50 & $2.43 \pm 0.04^{\mathrm{c}}$ & $0.340 \pm 0.02^{\mathrm{c}}$ & $167.2 \pm 1.72^{\mathrm{c}}$ & $1556.9 \pm 88.7^{\mathrm{c}}$ & $3.9 \pm 0.08^{\mathrm{c}}$ & $60.0 \pm 5.0^{\mathrm{ab}}$ \\
70 & $3.00 \pm 0.06^{\mathrm{a}}$ & $0.595 \pm 0.02^{\mathrm{a}}$ & $206.6 \pm 3.79^{\mathrm{a}}$ & $2700.0 \pm 54.5^{\mathrm{a}}$ & $4.6 \pm 0.03^{\mathrm{a}}$ & $77.5 \pm 7.5^{\mathrm{a}}$ \\
90 & $2.74 \pm 0.02^{\mathrm{b}}$ & $0.475 \pm 0.02^{\mathrm{b}}$ & $188.6 \pm 1.04^{\mathrm{b}}$ & $2170.5 \pm 75.0^{\mathrm{b}}$ & $4.3 \pm 0.05^{\mathrm{b}}$ & $75.0 \pm 10.0^{\mathrm{ab}}$ \\
110 & $1.51 \pm 0.06^{\mathrm{f}}$ & $0.185 \pm 0.02^{\mathrm{ef}}$ & $104.1 \pm 4.14^{\mathrm{f}}$ & $838.7 \pm 61.4^{\mathrm{e}}$ & $3.1 \pm 0.09^{\mathrm{f}}$ & $22.5 \pm 2.5^{\mathrm{c}}$ \\
130 & $1.40 \pm 0.05^{\mathrm{fg}}$ & $0.145 \pm 0.01^{\mathrm{f}}$ & $96.6 \pm 3.45^{\mathrm{fg}}$ & $652.3 \pm 11.4^{\mathrm{f}}$ & $2.8 \pm 0.02^{\mathrm{g}}$ & $17.5 \pm 2.5^{\mathrm{c}}$ \\
\hline
\end{tabular}

Means in the same column bearing different superscript letters differ significantly at $\mathrm{P} \leq 0.01$

Table 4. Average $(X \pm S E)$ feed intake $\left(g\right.$ larvae $\left.^{-1}\right)$, feed conversion ratio, feed efficiency ratio and protein efficiency ratio of Macrobrachium rosenbergii post-larvae fed with practical basal diet with graded level of zinc $(n=3)$

\begin{tabular}{|c|c|c|c|c|}
\hline $\begin{array}{l}\text { Zinc conc. } \\
\text { ( } \mathrm{mg} \mathrm{kg}^{-1} \\
\text { diet) }\end{array}$ & $\begin{array}{l}\text { Average feed intake } \\
\quad\left(\mathrm{g} \text { larvae }{ }^{-1}\right)\end{array}$ & $\begin{array}{l}\text { Average feed } \\
\text { conversion ratio } \\
\text { (FCR) }\end{array}$ & $\begin{array}{l}\text { Average feed } \\
\text { efficiency ratio } \\
\text { (FER) }\end{array}$ & $\begin{array}{lr}\text { Average } & \text { Protein } \\
\text { efficiency } & \text { ratio } \\
\text { (PER) } & \end{array}$ \\
\hline control & $0.29 \pm 0.00^{\mathrm{d}}$ & $1.62 \pm 0.04^{\mathrm{bcd}}$ & $0.62 \pm 0.02^{\mathrm{cd}}$ & $1.75 \pm 0.05^{\mathrm{bcd}}$ \\
\hline 10 & $0.35 \pm 0.00^{\mathrm{c}}$ & $1.66 \pm 0.03^{\mathrm{bcd}}$ & $0.60 \pm 0.01^{\mathrm{cd}}$ & $1.65 \pm 0.05^{\mathrm{cd}}$ \\
\hline 30 & $0.43 \pm 0.01^{\mathrm{bc}}$ & $1.50 \pm 0.06^{\mathrm{bc}}$ & $0.67 \pm 0.03^{\mathrm{bcd}}$ & $1.85 \pm 0.05^{\mathrm{bcd}}$ \\
\hline 50 & $0.48 \pm 0.01^{\mathrm{b}}$ & $1.41 \pm 0.10^{\mathrm{abc}}$ & $0.72 \pm 0.05^{\mathrm{bc}}$ & $2.00 \pm 0.10^{\mathrm{bc}}$ \\
\hline 70 & $0.71 \pm 0.08^{\mathrm{a}}$ & $1.20 \pm 0.16^{\mathrm{ab}}$ & $0.84 \pm 0.10^{\mathrm{a}}$ & $2.30 \pm 0.25^{\mathrm{ab}}$ \\
\hline 90 & $0.52 \pm 0.01^{\mathrm{b}}$ & $1.09 \pm 0.03^{\mathrm{a}}$ & $0.92 \pm 0.02^{\mathrm{a}}$ & $2.55 \pm 0.05^{\mathrm{a}}$ \\
\hline 110 & $0.35 \pm 0.01^{\mathrm{c}}$ & $1.87 \pm 0.12^{\mathrm{d}}$ & $0.54 \pm 0.04^{\mathrm{d}}$ & $1.50 \pm 0.10^{\mathrm{cd}}$ \\
\hline 130 & $0.24 \pm 0.03^{\mathrm{d}}$ & $1.67 \pm 0.18^{\mathrm{cd}}$ & $0.61 \pm 0.07^{\text {cd }}$ & $1.70 \pm 0.20^{\mathrm{bcd}}$ \\
\hline
\end{tabular}

Means in the same column bearing different superscript letters differ significantly at $\mathrm{P} \leq 0.01$

Table 5. Proximate body composition analysis $(X \pm S E)$ of moisture, protein lipid and ash of Macrobrachium rosenbergii post-larvae fed with practical basal diet with graded level of zinc. Values are mean $\pm S E$ of three replicates $(n=3)$

\begin{tabular}{ccccc}
\hline $\begin{array}{c}\text { Zinc conc. } \\
\left(\begin{array}{c}\mathrm{mg} \mathrm{kg}^{-1} \\
\text { diet })\end{array}\right.\end{array}$ & $\begin{array}{c}\text { Moisture } \\
(\%)\end{array}$ & $\begin{array}{c}\text { Protein } \\
(\%)\end{array}$ & $\begin{array}{c}\text { Lipid } \\
(\%)\end{array}$ & $\begin{array}{c}\text { Ash } \\
(\%)\end{array}$ \\
\hline control & $72.7 \pm 1.14$ & $52.2 \pm 0.49$ & $11.2 \pm 0.35^{\mathrm{b}}$ & $6.03 \pm 0.12^{\mathrm{b}}$ \\
10 & $73.2 \pm 1.30$ & $55.7 \pm 1.73$ & $11.8 \pm 0.66^{\mathrm{b}}$ & $5.93 \pm 0.41^{\mathrm{b}}$ \\
30 & $76.6 \pm 0.52$ & $53.5 \pm 2.47$ & $14.9 \pm 0.70^{\mathrm{a}}$ & $6.53 \pm 0.22^{\mathrm{ab}}$ \\
50 & $75.4 \pm 0.78$ & $52.8 \pm 3.11$ & $12.4 \pm 0.46^{\mathrm{b}}$ & $5.93 \pm 0.27^{\mathrm{b}}$ \\
70 & $74.9 \pm 0.81$ & $54.5 \pm 1.90$ & $10.9 \pm 0.49^{\mathrm{b}}$ & $6.57 \pm 0.19^{\mathrm{ab}}$ \\
90 & $73.6 \pm 1.32$ & $48.9 \pm 0.80$ & $11.6 \pm 0.46^{\mathrm{b}}$ & $6.70 \pm 0.12^{\mathrm{ab}}$ \\
110 & $75.0 \pm 0.80$ & $52.7 \pm 2.00$ & $12.0 \pm 0.40^{\mathrm{b}}$ & $6.93 \pm 0.22^{\mathrm{a}}$ \\
130 & $76.2 \pm 0.50$ & $51.7 \pm 0.44$ & $12.6 \pm 0.40^{\mathrm{b}}$ & $7.13 \pm 0.20^{\mathrm{a}}$ \\
\hline
\end{tabular}

Means in the same column bearing different superscript letters differ significantly at $\mathrm{P} \leq 0.01$ 


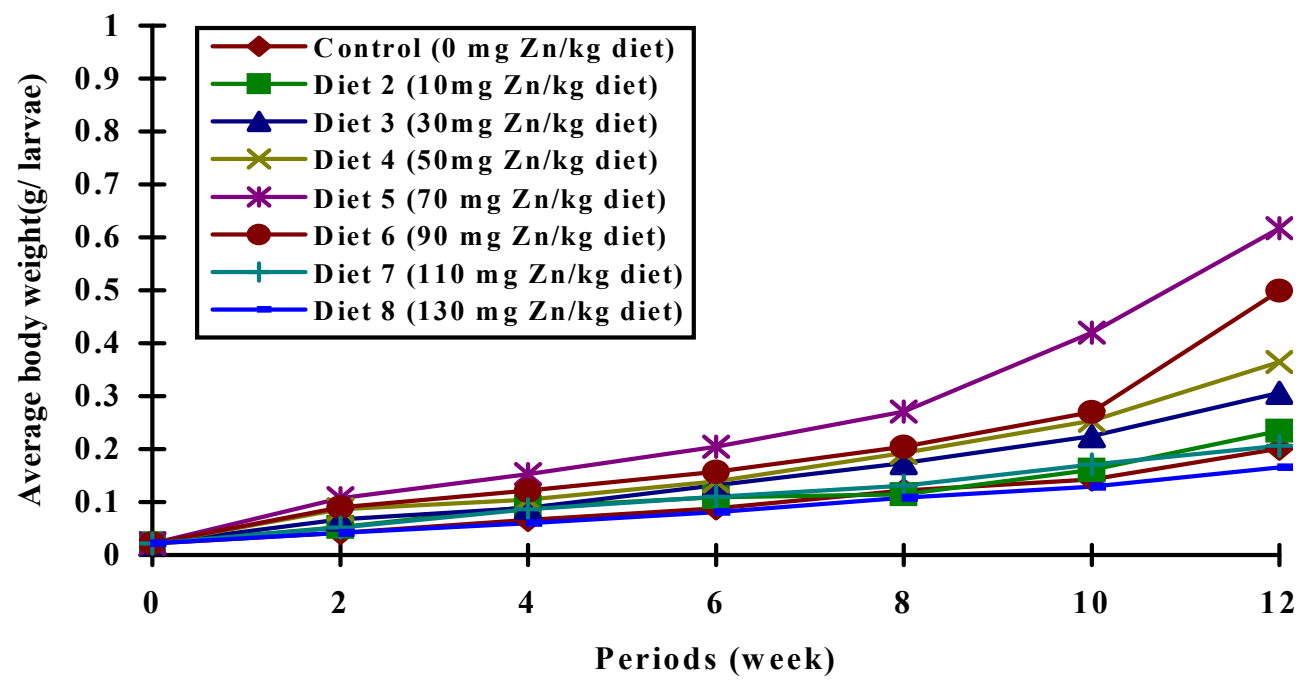

Figure 1. Changes in average body weight of Macrobrachium rosenbergii post-larvae fed with practical basal diet with graded level of zinc for a period of 12 week

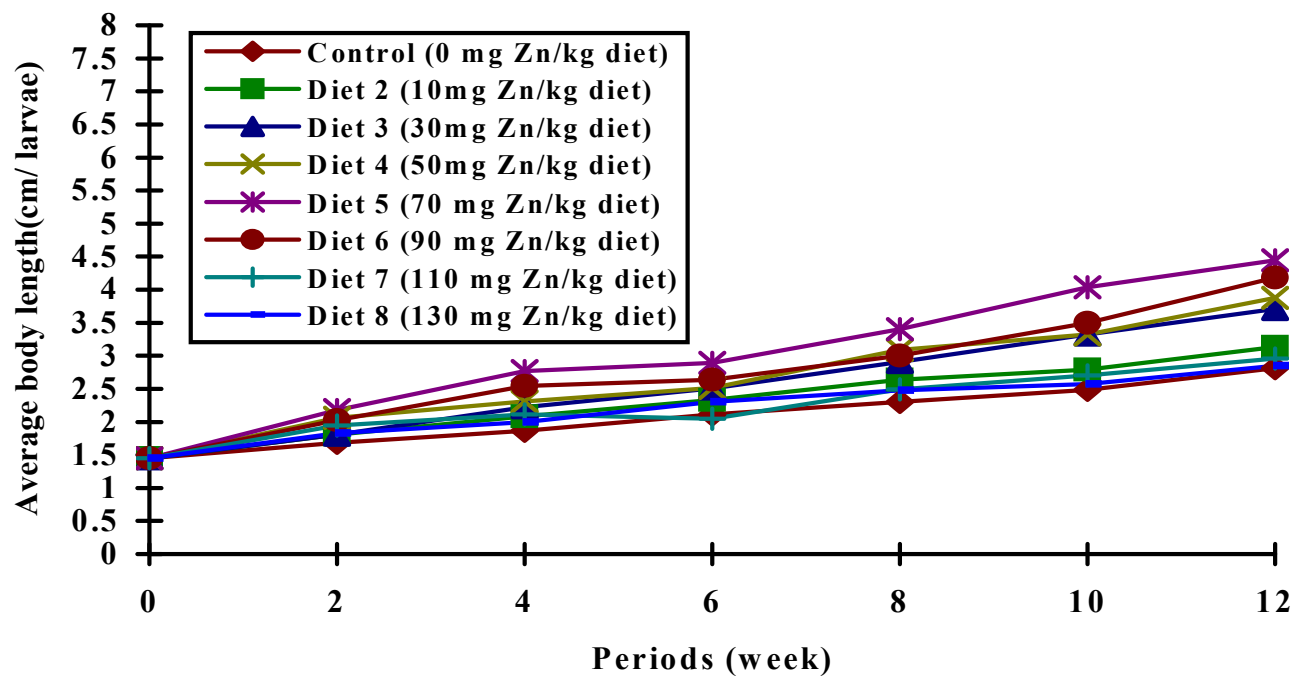

Figure 2. Changes in average body length of Macrobrachium rosenbergii post-larvae fed with practical basal diet with graded level of zinc for a period of $12 \mathrm{week}$ 
الآداء الإنتاجى ليرقات جمبرى المياة العذبة التى تتفذى على عليقة أساسية تحتوى مستويات مختلفة من الزنك.

\section{دياب محمد سعد دياب الصعيدى'، مادلين حبثى'}

ا ـ قسم إنتاج الدواجن، كليه الزراعة بشبين الكوم، جامعة المنوفية، مصر، r ـ محطة بحوث الأسماك بالقناطر الخيرية، المعطر القومى لعلوم البحار والمصايد، مصر البراعل

تهذف هذة الدراسة الى تقييم تأثير إضافة عنصر الزنكك الى العلائق على النمو والاداء ومعدل الحيوية والاستفادة الغذائية ومكونات

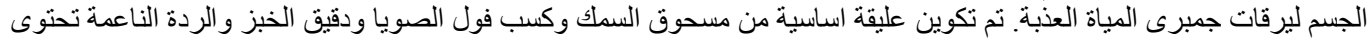

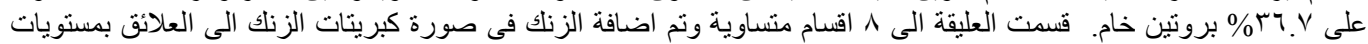

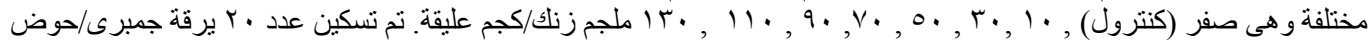

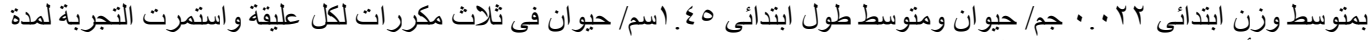

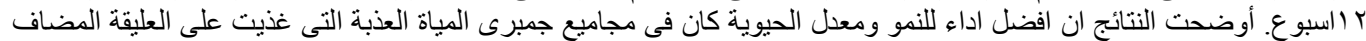

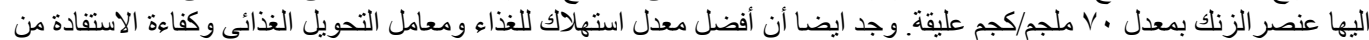

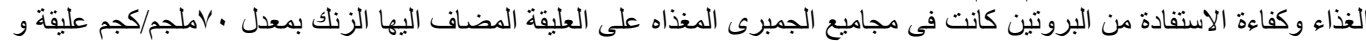

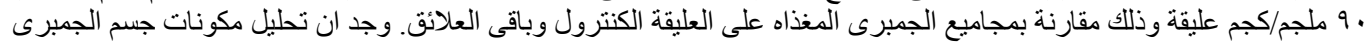

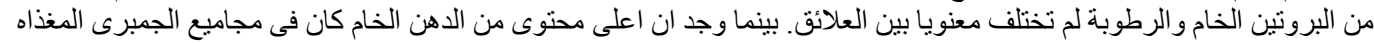

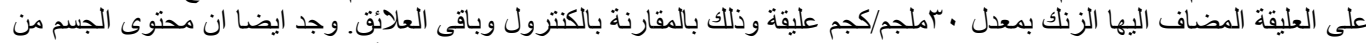

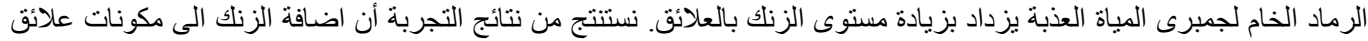

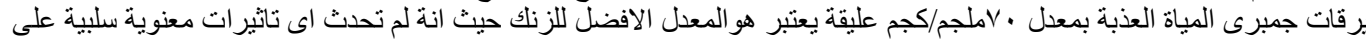

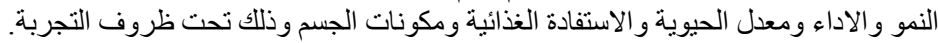

